\title{
Identification of Catalposide Metabolites in Human Liver and Intestinal Preparations and Characterization of the Relevant Sulfotransferase, UDP-glucuronosyltransferase, and Carboxylesterase Enzymes
}

\author{
Deok-Kyu Hwang ${ }^{1,+}{ }^{+}$Ju-Hyun Kim ${ }^{2,+}{ }^{\circledR}$, Yongho Shin ${ }^{1}{ }^{(}$, Won-Gu Choi $^{1}$, Sunjoo Kim ${ }^{1}{ }^{1}$, \\ Yong-Yeon Cho ${ }^{1}$, Joo Young Lee ${ }^{1}$, Han Chang Kang ${ }^{1(\mathbb{D})}$ and Hye Suk Lee ${ }^{1, * \mathbb{D}}$ \\ 1 BK21 PLUS Team for Creative Leader Program for Pharmacomics-based Future Pharmacy, \\ College of Pharmacy, The Catholic University of Korea, Bucheon 14662, Korea \\ 2 College of Pharmacy, Yeungnam University, Gyeongsan 38541, Korea \\ * Correspondence: sianalee@catholic.ac.kr; Tel.: +82-2-2164-4061; Fax: +82-32-342-2013 \\ + These authors contributed equally to this work.
}

Received: 24 June 2019; Accepted: 19 July 2019; Published: 22 July 2019

\begin{abstract}
Catalposide, an active component of Veronica species such as Catalpa ovata and Pseudolysimachion lingifolium, exhibits anti-inflammatory, antinociceptic, anti-oxidant, hepatoprotective, and cytostatic activities. We characterized the in vitro metabolic pathways of catalposide to predict its pharmacokinetics. Catalposide was metabolized to catalposide sulfate (M1), 4-hydroxybenzoic acid (M2), 4-hydroxybenzoic acid glucuronide (M3), and catalposide glucuronide (M4) by human hepatocytes, liver S9 fractions, and intestinal microsomes. M1 formation from catalposide was catalyzed by sulfotransferases (SULTs) 1C4, SULT1A1*1, SULT1A1*2, and SULT1E1. Catalposide glucuronidation to M4 was catalyzed by gastrointestine-specific UDP-glucuronosyltransferases (UGTs) 1A8 and UGT1A10; M4 was not detected after incubation of catalposide with human liver preparations. Hydrolysis of catalposide to M2 was catalyzed by carboxylesterases (CESs) 1 and 2, and M2 was further metabolized to M3 by UGT1A6 and UGT1A9 enzymes. Catalposide was also metabolized in extrahepatic tissues; genetic polymorphisms of the carboxylesterase (CES), UDP-glucuronosyltransferase (UGT), and sulfotransferase (SULT) enzymes responsible for catalposide metabolism may cause inter-individual variability in terms of catalposide pharmacokinetics.
\end{abstract}

Keywords: catalposide; in vitro human metabolism; UDP-glucuronosyltransferase; sulfotransferase; carboxylesterase

\section{Introduction}

Catalposide is an active iridoid glycoside of Veronica species including Catalpa ovata and Pseudolysimachion lingifolium [1-3]. Catalposide exhibits various biological effects including anti-inflammatory [4-9], anti-oxidant [10], antinociceptic [8], cytostatic [11], hypolipidemic via peroxisome proliferator-activated receptor- $\alpha$ activation [12], and hepatoprotective activities [13].

Catalposide had a short half-life $(19.3 \pm 9.5 \mathrm{~min})$, and exhibited high systemic clearance $(96.7 \pm 44.1 \mathrm{~mL} / \mathrm{min} / \mathrm{kg})$, and low urinary excretion $(9.9 \pm 4.1 \%$ of the dose) after intravenous administration of $10 \mathrm{mg} / \mathrm{kg}$ to male Sprague-Dawley rats [14]. This indicated that catalposide might be extensively metabolized in rats. However, catalposide remained stable after $1 \mathrm{~h}$ incubation 
with rat liver microsomes in the presence of NADPH [14]. Thus, catalposide may be catabolized via non-cytochrome P450 (CYP)-mediated mechanism. Catalposide was the substrate of OAT3, OATP1B1, and OATP1B3 transporters and weakly inhibited their transport activities with $\mathrm{IC}_{50}$ values of 83 , 200, and $235 \mu \mathrm{M}$, respectively, suggesting that OAT3, OATP1B1, and OATP1B3 may regulate the pharmacokinetics and drug interactions of catalposide [15].

Pharmacokinetics and metabolism of potential active constituents in herbal drugs is helpful for the determination of dosage regimens and interpretation of pharmacological effects under clinical conditions [16]. It is important to establish the comparative metabolism and drug-metabolizing enzymes of active constituents for a full characterization of its pharmacokinetics, pharmacodynamics, and toxicity. The characterization of drug-metabolizing enzymes such as CYPs, carboxylesterases (CESs), UDP-glucuronosyltransferases (UGTs), and sulfotransferases (SULTs) responsible for the metabolism of a drug may reveal inter-individual variability in drug metabolism and the potential drug interactions [17-19]. However, catalposide metabolism has not been studied in humans and animals. We identified catalposide metabolites and drug-metabolizing enzymes involved to predict its pharmacokinetics and possible drug interactions.

We identified catalposide metabolites formed from in vitro incubations of catalposide with human hepatocytes, intestinal microsomes, and liver S9 fractions using liquid chromatography-high resolution mass spectrometry (LC-HRMS) and characterized the CES, UGT, and SULT enzymes involved in catalposide metabolism using human cDNA-expressed CES, UGT, and SULT supersomes, respectively.

\section{Materials and Methods}

\subsection{Materials and Reagents}

Catalposide (purity, 98\%) was obtained from Aobious Inc. (Gloucester, MA, USA). Alamethicin, 3-phosphoadenosine-5-phosphosulfate (PAPS), and uridine 5' -diphosphoglucuronic acid (UDPGA) were from Sigma-Aldrich Co. (St. Louis, MO, USA). 4-hydroxybenzoic acid and 4-hydroxybenzoic acid glucuronide were purchased from Toronto Research Chemicals (North York, ON, Canada). Pooled human intestinal microsomes; pooled human liver S9 fractions; human cDNA-expressed UGTs 1A1/3/4/6/7/8/9/10 and 2B4/7/15/17 supersomes; human cDNA-expressed CESs 1b, 1c, and 2 supersomes; cryopreserved human hepatocytes; and hepatocyte purification kits were obtained from Corning Life Sciences (Woburn, MA, USA). Human cDNA-expressed SULT 1A1*1, 1A1*2, 1A2, 1A3, 1B1, 1C2, 1C4, 1E1, and 2A1 supersomes were purchased from Cypex Ltd. (Dundee, UK). Methanol (HPLC grade) was from Burdick \& Jackson Inc. (SK Chemicals, Ulsan, Korea), and all other chemicals were of the highest quality available. Calibration mixtures for Exactive MS [ProteoMass LTQ/FT-hybrid ESI positive mode Cal Mix (MSCAL5) and negative mode Cal Mix (MSCAL6)] were obtained from Supelco (Bellefonte, PA, USA).

\subsection{In Vitro Metabolism of Catalposide in Cryopreserved Human Hepatocytes}

Cryopreserved human hepatocytes were recovered with the aid of a hepatocyte purification kit, and viable cells were resuspended in William's E buffer at a final concentration of $1.28 \times 10^{6}$ cells $/ \mathrm{mL}$ [20]. Human hepatocyte suspensions $\left(62.5 \mu \mathrm{L}, 8.00 \times 10^{4}\right.$ cells $)$ and $62.5 \mu \mathrm{L}$ of $400 \mu \mathrm{M}$ catalposide in William's E buffer were added to the wells of a 96-well plate and the mixture was incubated for $120 \mathrm{~min}$ at $37^{\circ} \mathrm{C}$ in a $\mathrm{CO}_{2}$ incubator. Methanol $(250 \mu \mathrm{L})$ was added to each well and the mixture was centrifuged at $3000 \times g$ for $10 \mathrm{~min}$. Aliquots of the supernatants $(250 \mu \mathrm{L})$ were evaporated to dryness using a vacuum evaporator (Genevac Ltd., Ipswich, UK). Each residue was dissolved in $100 \mu \mathrm{L}$ of 5\% methanol and an aliquot $(5 \mu \mathrm{L})$ was injected into the LC-HRMS system.

\subsection{In Vitro Metabolism of Catalposide in Human Liver S9 Fractions and Intestinal Microsomes}

Each reaction mixture contained $50 \mathrm{mM}$ potassium phosphate buffer ( $\mathrm{pH}$ 7.4), $10 \mathrm{mM}$ magnesium chloride, human liver S9 fractions or human intestinal microsomes (100 $\mu$ g protein), 2 mM UDPGA or 
$200 \mu \mathrm{M}$ PAPS, $200 \mu \mathrm{M}$ catalposide or a possible metabolite, and $1000 \mu \mathrm{M}$ 4-hydroxybenzoic acid in a volume of $200 \mu \mathrm{L}$. Samples lacking UDPGA and PAPS served as controls. The mixtures were incubated at $37^{\circ} \mathrm{C}$ for $60 \mathrm{~min}$ and the reactions were then quenched by adding $500 \mu \mathrm{L}$ of methanol. The tubes were centrifuged and the supernatants evaporated to dryness using a vacuum concentrator. The residues were dissolved in $100 \mu \mathrm{L}$ of $5 \%$ methanol and $5 \mu \mathrm{L}$ aliquots were injected into the LC-HRMS system.

\subsection{Characterization of Human SULTs Involved in Catalposide Sulfation}

To screen for SULT enzymes involved in catalposide sulfation, each $100 \mu \mathrm{L}$ of reaction mixture contained $20 \mu \mathrm{M}$ PAPS; $10 \mathrm{mM}$ dithiothreitol; $5 \mathrm{mM}$ magnesium chloride; $50 \mathrm{mM}$ phosphate buffer (pH 7.4); $150 \mu \mathrm{M}$ catalposide; and the human liver S9 fraction (40 $\mu$ g protein) or human cDNA-expressed SULT $1 \mathrm{~A} 1 * 1,1 \mathrm{~A} 1 * 2,1 \mathrm{~A} 2,1 \mathrm{~A} 3,2 \mathrm{~A} 1,1 \mathrm{~B} 1,1 \mathrm{C} 2,1 \mathrm{C} 4$, or $1 \mathrm{E} 1$ supersomes $\left[1 \mathrm{~A} 1{ }^{*} 1(0.25), 1 \mathrm{~A} 1 * 2(0.5), 1 \mathrm{~A} 2\right.$ (0.25), 1A3 (0.2), 2A1 (1.25), 1B1 (0.5), 1C2 (2.5), 1C4 (0.1), 1E1 (0.2 $\mu \mathrm{g}$ protein)]. Incubation proceeded at $37^{\circ} \mathrm{C}$ for $5 \mathrm{~min}$. The reactions were stopped by adding $100 \mu \mathrm{L}$ of methanol containing $30 \mathrm{ng} / \mathrm{mL}$ 4-methylumbelliferone (an internal standard). After vortex-mixing and centrifugation, $50 \mu \mathrm{L}$ of each supernatant was diluted with $50 \mu \mathrm{L}$ deionized water. The mixture was transferred to an injection vial, and an aliquot $(5 \mu \mathrm{L})$ was injected into the LC-HRMS system.

To explore the kinetics of the metabolism of catalposide to catalposide sulfate, various concentrations of catalposide $(10$ to $2000 \mu \mathrm{M})$ were incubated in duplicate with pooled human liver S9 fractions (40 $\mu \mathrm{g}$ protein) or human cDNA-expressed SULT1A1*1 (0.5 $\mu$ g protein), SULT1A1*2 $(0.5 \mu \mathrm{g}$ protein), SULT1C4 (0.1 $\mu \mathrm{g}$ protein), or SULT1E1 ( $0.2 \mu \mathrm{g}$ protein) in the presence of $20 \mu \mathrm{M}$ PAPS, $10 \mathrm{mM}$ dithiothreitol, and $5 \mathrm{mM}$ magnesium chloride at $37^{\circ} \mathrm{C}$ for $5 \mathrm{~min}$ to obtain $K_{\mathrm{m}}$ and $V_{\max }$ values.

\subsection{Characterization of Human UGTs Involved in Catalposide and 4-Hydroxybenzoic Acid Glucuronidation}

To identify the UGT enzymes responsible for formation of catalposide glucuronide (M4) from catalposide and 4-hydroxybenzoic acid glucuronide (M3) from 4-hydroxybenzoic acid (M2), $100 \mu \mathrm{L}$ reaction mixtures containing human intestinal microsomes ( $40 \mu \mathrm{g}$ protein), or human cDNA-expressed UGTs 1A1, 1A3, 1A4, 1A6, 1A7, 1A8, 1A9, 1A10, 2B4, 2B7, 2B15, or $2 \mathrm{~B} 17$ (10 $\mu \mathrm{g}$ protein); 2 mM UDPGA; $0.025 \mathrm{mg} / \mathrm{mL}$ alamethicin; and $400 \mu \mathrm{M}$ catalposide or $500 \mu \mathrm{M}$ 4-hydroxybenzoic acid in $50 \mathrm{mM}$ Tris buffer ( $\mathrm{pH} 7.4$ ) were incubated at $37^{\circ} \mathrm{C}$ for $60 \mathrm{~min}$. The reactions were stopped by addition of $100 \mu \mathrm{L}$ methanol containing $30 \mathrm{ng} / \mathrm{mL}$ 4-methylumbelliferone (an internal standard). After vortex-mixing and centrifugation, $50 \mu \mathrm{L}$ of each supernatant was diluted with an equal volume of water and a $5 \mu \mathrm{L}$ aliquot was injected into the LC-HRMS system.

To explore the kinetics of the metabolism of catalposide to catalposide glucuronide, various concentrations of catalposide $(10,25,100,400,800,1200,1600$, and $2000 \mu \mathrm{M})$ were incubated in duplicate with $2 \mathrm{mM}$ UDPGA, $0.025 \mathrm{mg} / \mathrm{mL}$ alamethicin, pooled human intestinal microsomes $(40 \mu \mathrm{g}$ protein), or human cDNA-expressed UGT1A8 or UGT1A10 supersomes (20 $\mu \mathrm{g}$ protein), to obtain $K_{\mathrm{m}}$ and $V_{\max }$ values.

\subsection{Characterization of Carboxylesterases Involved in the Formation of 4-Hydroxybenzoic Acid from Catalposide}

To identify the CES enzymes involved in hydrolysis of catalposide to 4-hydroxybenzoic acid, $100 \mu \mathrm{L}$ reaction mixtures containing human liver S9 fractions; human intestinal microsomes; or human CES1b, CES1c, or CES2 enzymes (50 $\mu$ g protein), and catalposide ( 200 or $400 \mu \mathrm{M})$ in $50 \mathrm{mM}$ phosphate buffer ( $\mathrm{pH} 7.4$ ) were incubated at $37^{\circ} \mathrm{C}$ for $30 \mathrm{~min}$. Reactions were stopped by addition of $100 \mu \mathrm{L} 4$-methylumbelliferone (internal standard, $10 \mathrm{ng} / \mathrm{mL}$ ) in methanol. After vortex-mixing and centrifugation, $50 \mu \mathrm{L}$ of each supernatant was diluted with $50 \mu \mathrm{L}$ of deionized water. Each mixture was transferred to an injection vial, and a $5 \mu \mathrm{L}$ aliquot was injected into the LC-HRMS system. 


\subsection{LC-HRMS Analysis of Catalposide and Metabolites}

To separate and identify catalposide and its metabolites, we used a Q-Exactive Orbitrap mass spectrometer coupled to an Accela UPLC system (Thermo Scientific, Waltham, MA, USA). Catalposide and its metabolites were optimally separated on a Halo C18 column via gradient elution using 5\% $(v / v)$ methanol in $1 \mathrm{mM}$ ammonium formate ( $\mathrm{pH}$ 3.1) (mobile phase A) and methanol (mobile phase B) at a flow rate of $0.5 \mathrm{~mL} / \mathrm{min}$ : $5 \%$ mobile phase $B$ for $2 \mathrm{~min}, 5-20 \%$ mobile phase B over $11.5 \mathrm{~min}$, $20-90 \%$ mobile phase B over $0.5 \mathrm{~min}, 90 \%$ mobile phase B for $3 \mathrm{~min}, 90-5 \%$ mobile phase B over $0.5 \mathrm{~min}$, and $5 \%$ mobile phase B for $2.5 \mathrm{~min}$. The column and the autosampler were maintained at 40 and $6{ }^{\circ} \mathrm{C}$, respectively. Accurate mass measurements of catalposide and its metabolites were derived via electrospray ionization in the negative mode using the following electrospray source settings: ion transfer capillary temperature, $330^{\circ} \mathrm{C}$; needle spray voltage, $-3000 \mathrm{~V}$; capillary voltage, $-47.5 \mathrm{~V}$; nitrogen sheath gas, 50 arbitrary units; auxiliary gas, 15 arbitrary units. The resolution and automatic gain control were scaled to 70,000 and 1,000,000, respectively. MS data were obtained using external calibration over the scan range $m / z$ 100-700 and processed using Xcalibur software version 2.2 (Thermo Scientific). The Q-Exactive Orbitrap MS was calibrated using MSCAL5 and MSCAL6 for the positive and negative ion modes, respectively. Nitrogen gas was employed for higher-energy collision dissociation (HCD) at an energy of $25 \mathrm{eV}$ to obtain product ion spectra of catalposide and its metabolites. Structures were determined using Mass Frontier software (version 6.0; HighChem Ltd., Bratislava, Slovakia). We used the extracted ion monitoring mode for quantification: $m / z 481.1349$ for catalposide, $m / z 657.1674$ for catalposide glucuronide, $m / z 561.0921$ for catalposide sulfate, $\mathrm{m} / \mathrm{z} 137.0239$ for 4-hydroxybenzoic acid, $\mathrm{m} / \mathrm{z} 313.0569$ for 4-hydroxybenzoic acid glucuronide, and $\mathrm{m} / \mathrm{z} 175.0410$ for 4-methylumbelliferone (the internal standard). The peak areas of all components were integrated using Xcalibur software. The calibration curve was linear over the catalposide concentration range 0.5-200 pmol. The concentrations of catalposide glucuronide and catalposide sulfate were calculated using the calibration curve for catalposide because we had no authentic standards.

\subsection{Data Analysis}

All results are the average of two determinations obtained using pooled human intestinal microsomes, pooled human liver S9 fractions, UGTs, and SULTs. The apparent kinetic parameters $\left(K_{\mathrm{m}}\right.$, $V_{\max }, \mathrm{n}$, and $K_{\mathrm{i}}$ ) for formation of catalposide glucuronide or catalposide sulfate by human intestinal microsomes, liver S9 fractions, UGTs, or SULTs were determined by fitting the Hill equation model $\left[V=V_{\max } \mathrm{S}^{\mathrm{n}} /\left(K_{\mathrm{m}}{ }^{\mathrm{n}}+\mathrm{S}^{\mathrm{n}}\right)\right]$, the substrate inhibition model $\left[V=V_{\max } /\left(1+K_{\mathrm{m}} / \mathrm{S}+\mathrm{S} / K_{\mathrm{i}}\right)\right]$, or the single enzyme model $\left[V=V_{\max } \mathrm{S} /\left(K_{\mathrm{m}}+\mathrm{S}\right)\right]$ to the unweighted formation rates of catalposide glucuronide and catalposide sulfate, respectively, over a range of catalposide concentrations using Enzyme Kinetics software (version 1.1 SPSS Science Inc., Chicago, IL, USA). In the above equations, $V$ is the velocity of the reaction at substrate concentration [S], $V_{\max }$ is the maximum velocity, $\mathrm{n}$ is the Hill constant, $K_{\mathrm{m}}$ is the substrate concentration at which the reaction velocity is $50 \%$ of $V_{\max }$, and $K_{\mathrm{i}}$ is the dissociation constant of the substrate binding to the inhibitory region within the enzyme active site.

\section{Results}

\subsection{In Vitro Metabolic Profiles of Catalposide Incubated with Human Hepatocytes and Intestinal Microsomes}

LC-HRMS analysis of extracts after incubation of catalposide with human hepatocytes revealed three metabolites (M1-M3) and residual catalposide (Figure 1A). LC-HRMS analysis of reaction mixtures after incubation of catalposide with human intestinal microsomes in the presence of UDPGA yielded M2, M3, and a new metabolite M4 (Figure 1B). 
A

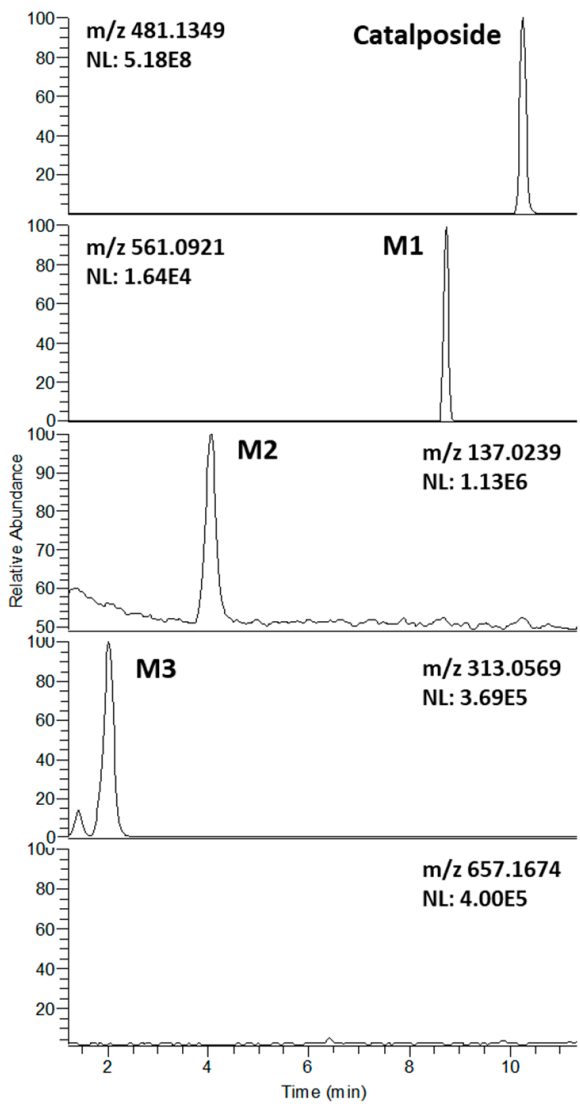

B

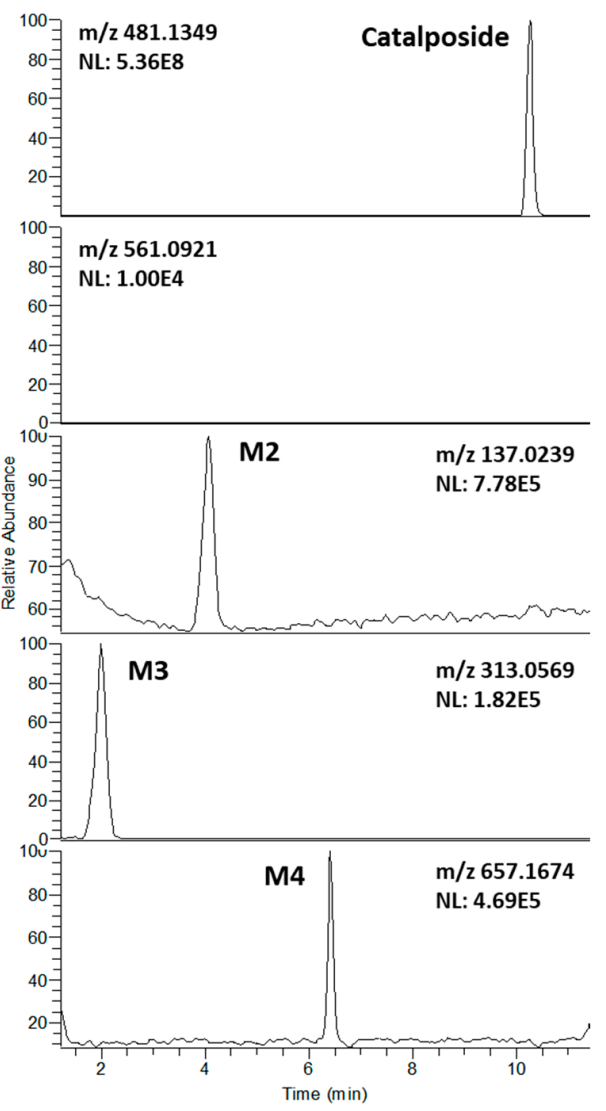

Figure 1. Extracted ion chromatograms of catalposide and its possible metabolites after incubation of $200 \mu \mathrm{M}$ catalposide with (A) human hepatocytes for $2 \mathrm{~h}$ at $37^{\circ} \mathrm{C}$ in a $\mathrm{CO}_{2}$ incubator and (B) human intestinal microsomes in the presence of UDPGA at $37^{\circ} \mathrm{C}$ for $1 \mathrm{~h}$ (mass accuracy: $5 \mathrm{ppm}$ ). The extracted ion chromatograms were reconstructed based on the $[\mathrm{M}-\mathrm{H}]^{-}$ions: $\mathrm{m} / \mathrm{z} 481.1349$ for catalposide, $\mathrm{m} / \mathrm{z}$ 561.0921 for M1 (catalposide sulfate), $m / z$ 137.0239 for M2 (4-hydroxybenzoic acid), $m / z$ 313.0569 for M3 (4-hydroxybenzoic acid glucuronide), and $\mathrm{m} / \mathrm{z} 657.1674$ for M4 (catalposide glucuronide).

The formulae, deprotonated molecular ions $\left([\mathrm{M}-\mathrm{H}]^{-}\right)$, mass errors, and retention times of catalposide and its four metabolites, M1-M4, are shown in Table 1. The four metabolite peaks were identified using the accurate mass values and the characteristic product ions of the product scan spectra (Table 1, Figure 2). The mass errors between the theoretical and observed $m / z$ values for each metabolite were less than 5 ppm, indicating good correlations between the calculated theoretical masses and the experimentally observed masses obtained after full-scan MS analysis.

Table 1. Molecular formulae, deprotonated molecular ions $\left([\mathrm{M}-\mathrm{H}]^{-}\right)$, mass errors, retention times $\left(\mathrm{t}_{\mathrm{R}}\right)$, and product ions of catalposide and its metabolites were identified after incubation of catalposide with human hepatocytes and intestinal microsomes.

\begin{tabular}{cccccc}
\hline Metabolite & Formula & $\begin{array}{c}\text { Exact Mass } \\
{[\mathbf{M}-\mathbf{H}]^{-}(m / z)}\end{array}$ & Error (ppm) & $\mathbf{t}_{\mathbf{R}}(\mathbf{m i n})$ & Product Ions $(\boldsymbol{m} / \mathbf{z})$ \\
\hline Catalposide & $\mathrm{C}_{22} \mathrm{H}_{26} \mathrm{O}_{12}$ & 481.1349 & -0.6 & 10.26 & $319.0822,205.0497,137.0239$ \\
\hline $\mathrm{M} 1$ & $\mathrm{C}_{22} \mathrm{H}_{26} \mathrm{SO}_{15}$ & 561.0921 & 0.2 & 8.74 & $481.1349,319.0822,205.0499,137.0239$ \\
\hline $\mathrm{M} 2$ & $\mathrm{C}_{7} \mathrm{H}_{6} \mathrm{O}_{3}$ & 137.0239 & -3.6 & 4.07 & 93.0339 \\
\hline $\mathrm{M} 3$ & $\mathrm{C}_{13} \mathrm{H}_{14} \mathrm{O}_{9}$ & 313.0569 & 1.3 & 2.02 & $\begin{array}{c}193.0345,175.0240,137.0239,113.0239, \\
85.0283\end{array}$ \\
\hline $\mathrm{M} 4$ & $\mathrm{C}_{28} \mathrm{H}_{34} \mathrm{O}_{18}$ & 657.1674 & 0.3 & 6.41 & $\begin{array}{c}481.1353,319.0823,205.0499,175.0240, \\
137.0239,113.0238,85.0283\end{array}$ \\
\hline
\end{tabular}



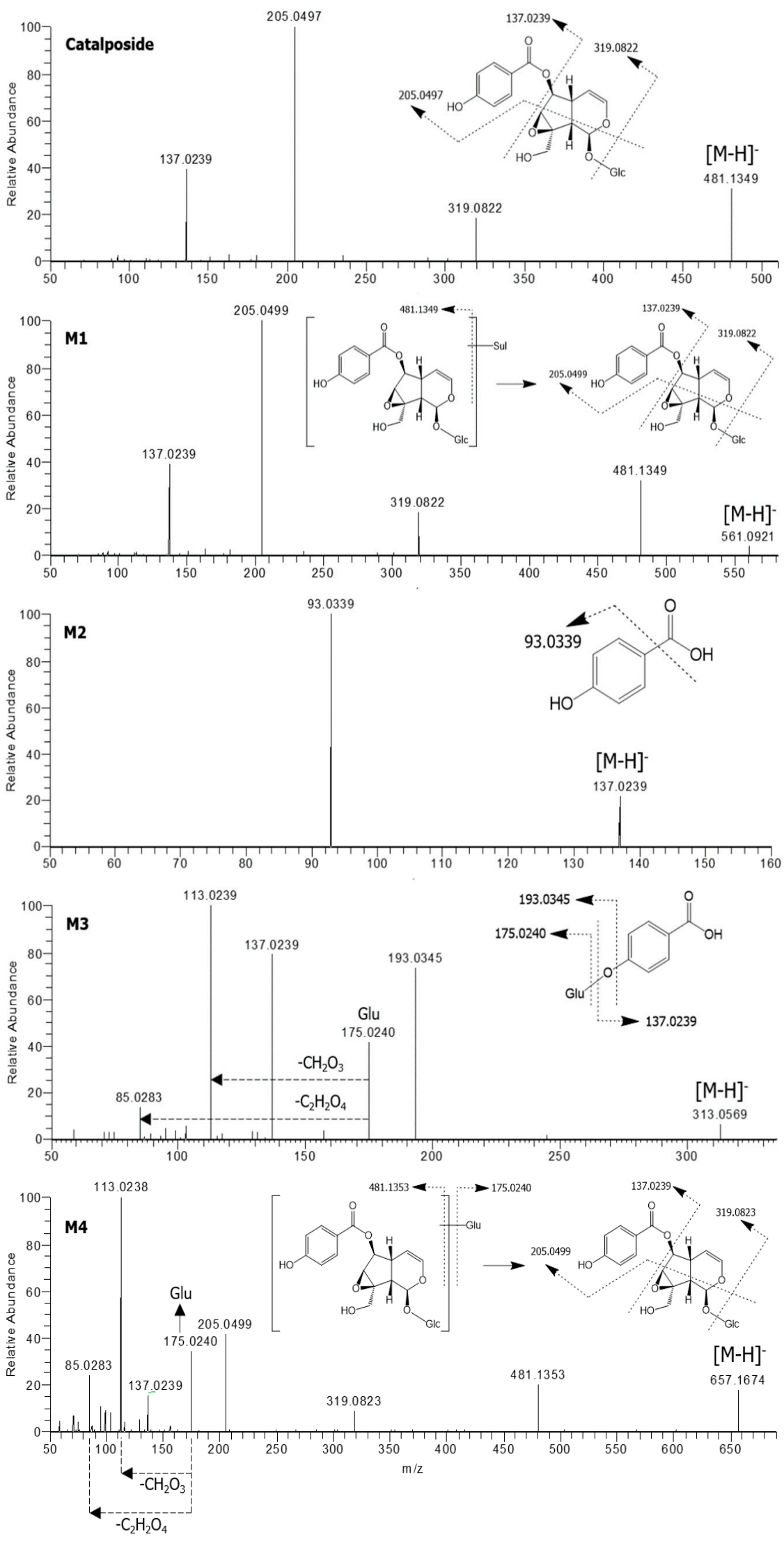

Figure 2. Product scan spectra of catalposide and its four metabolites, M1-M4 obtained via liquid chromatography-high resolution mass spectrometry (LC-HRMS) analysis of reaction mixtures obtained after incubation of catalposide with human intestinal microsomes in the presence of uridine 5'-diphosphoglucuronic acid (UDPGA) or human hepatocytes. Glc: glucose; Glu: glucuronosyl. 
The product scan spectra of catalposide exhibiting the $[\mathrm{M}-\mathrm{H}]^{-}$ion at $m / z 481.1349$ generated characteristic product ions at $m / z 319.0822$ (reflecting loss of glucose from the $[\mathrm{M}-\mathrm{H}]^{-}$ion), $\mathrm{m} / \mathrm{z} 205.0497$ (loss of $\mathrm{C}_{5} \mathrm{H}_{6} \mathrm{O}_{3}$ caused by the breakdown of the iridoid moiety of $\mathrm{m} / \mathrm{z} 319.0822$ ), and $\mathrm{m} / \mathrm{z} 137.0239$ (the 4-hydroxybenzoyl moiety) (Figure 2).

M1 exhibited an $[\mathrm{M}-\mathrm{H}]^{-}$ion at $\mathrm{m} / \mathrm{z} 561.0921$, that is, $80 \mathrm{amu}$ higher than the $[\mathrm{M}-\mathrm{H}]^{-}$ion of catalposide, indicating that M1 was catalposide sulfate. The product scan spectra of M1 generated the characteristic product ions at $m / z 481.1349$ (loss of $\mathrm{SO}_{3}$ from the $[\mathrm{M}-\mathrm{H}]^{-}$ion), $\mathrm{m} / z 319.0822$ (loss of glucose from $\mathrm{m} / \mathrm{z} 481.1349$ ), $\mathrm{m} / \mathrm{z} 205.0499$, and $\mathrm{m} / \mathrm{z} 137.0239$ (Figure 2). M1 was also formed from catalposide after incubation with human liver S9 fractions in the presence of PAPS. Thus, M1 was identified as catalposide sulfate.

M2 exhibited an $[\mathrm{M}-\mathrm{H}]^{-}$ion at $\mathrm{m} / \mathrm{z} 137.0239$ and generated a characteristic product ion at $\mathrm{m} / \mathrm{z}$ 93.0339 (reflecting loss of a carboxyl group from the $[\mathrm{M}-\mathrm{H}]^{-}$ion)(Figure 2). M2 was identified as 4-hydroxybenzoic acid by comparison with the mass, retention time, and product ion of the authentic standard.

M3 exhibited an $[\mathrm{M}-\mathrm{H}]^{-}$ion at $\mathrm{m} / \mathrm{z} 313.0569$, that is, $176 \mathrm{amu}$ higher than the $[\mathrm{M}-\mathrm{H}]^{-}$ion of M2 (4-hydroxybenzoic acid), reflecting glucuronidation of M2. In the product scan spectrum of M3, characteristic product ions were observed at $\mathrm{m} / \mathrm{z} 137.0239$ (reflecting loss of the glucuronosyl moiety from the $[\mathrm{M}-\mathrm{H}]^{-}$ion), $\mathrm{m} / \mathrm{z} 175.0240$ (the glucuronosyl moiety), and $\mathrm{m} / \mathrm{z} 113.0239$ (loss of $\mathrm{CO}_{2}$ and $\mathrm{H}_{2} \mathrm{O}$ from $\mathrm{m} / \mathrm{z}$ 175.0240) (Figure 2). Incubation of 4-hydroxybenzoic acid (M2) with human liver S9 fractions or intestinal microsomes in the presence of UDPGA yielded M3, which was identified as 4-hydroxybenzoic acid glucuronide by comparison with the mass, retention time, and product ions of the authentic standard.

M4 exhibited an $[\mathrm{M}-\mathrm{H}]^{-}$ion at $\mathrm{m} / \mathrm{z}$ 657.1674, that is, $176 \mathrm{amu}$ higher than the $[\mathrm{M}-\mathrm{H}]^{-}$ion of catalposide, reflecting catalposide glucuronidation. M4 yielded characteristic product ions at $\mathrm{m} / \mathrm{z}$ 481.1353 (reflecting loss of the glucuronosyl moiety from the $[\mathrm{M}-\mathrm{H}]^{-}$ion), $m / z 319.0823$ (loss of glucose from $\mathrm{m} / \mathrm{z}$ 481.1353), $\mathrm{m} / \mathrm{z}$ 205.0499, $\mathrm{m} / \mathrm{z}$ 175.0240, $\mathrm{m} / \mathrm{z} 113.0238$, and $\mathrm{m} / \mathrm{z} 85.0283$ (Figure 2). Thus, M4 was identified as catalposide glucuronide.

The possible in vitro metabolic pathways of catalposide in humans are shown in Figure 3. Catalposide is metabolized to catalposide sulfate (M1), catalposide glucuronide (M4), and 4-hydroxybenzoic acid (M2); the latter is then further metabolized to 4-hydroxybenzoic acid glucuronide (M3).

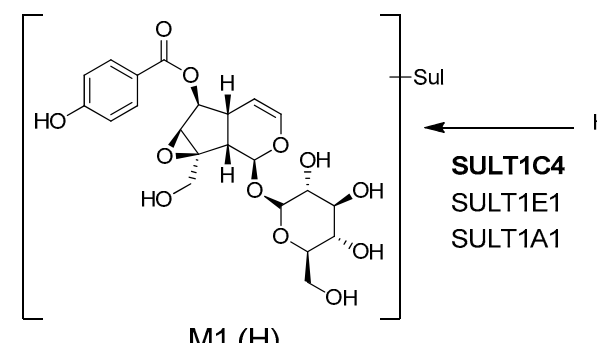

M1 (H)

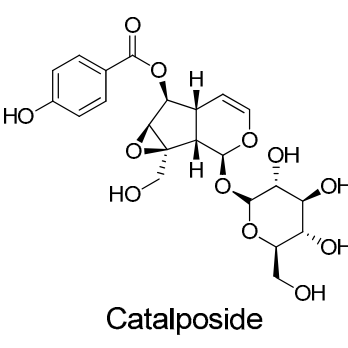

Catalposide

CES2

CES1b

CES1C

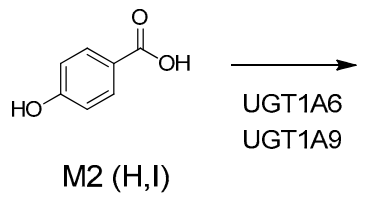

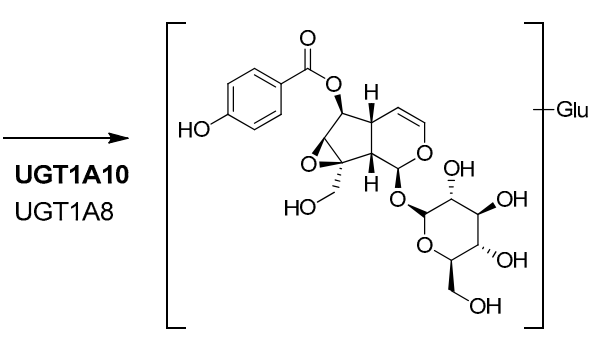

M4 (I)

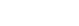<smiles>COc1ccc(C(=O)O)cc1</smiles>

Figure 3. Possible in vitro metabolic pathways of catalposide incubated with human hepatocytes and intestinal microsomes. H: human hepatocytes; I: human intestinal microsomes; Sul: sulfate; Glu: glucuronic acid; CES: carboxylesterase; UGT: UDP-glucuronosyltransferase; SULT: sulfotransferase. 


\subsection{Characterization of Human SULT, UGT, and CES Enzymes Involved in Catalposide Metabolism}

A screen using human cDNA-expressed SULTs $1 \mathrm{~A} 1 * 1,1 \mathrm{~A} 1 * 2,1 \mathrm{~A} 2,1 \mathrm{~A} 3,1 \mathrm{~B} 1,1 \mathrm{C} 2,1 \mathrm{C} 4,1 \mathrm{E} 1$, and $2 \mathrm{~A} 1$ to assess the formation of catalposide sulfate (M1) from catalposide identified possible roles for SULTs $1 \mathrm{~A} 1 * 1,1 \mathrm{~A} 1 * 2,1 \mathrm{C} 4$, and 1E1 (Figure 4).

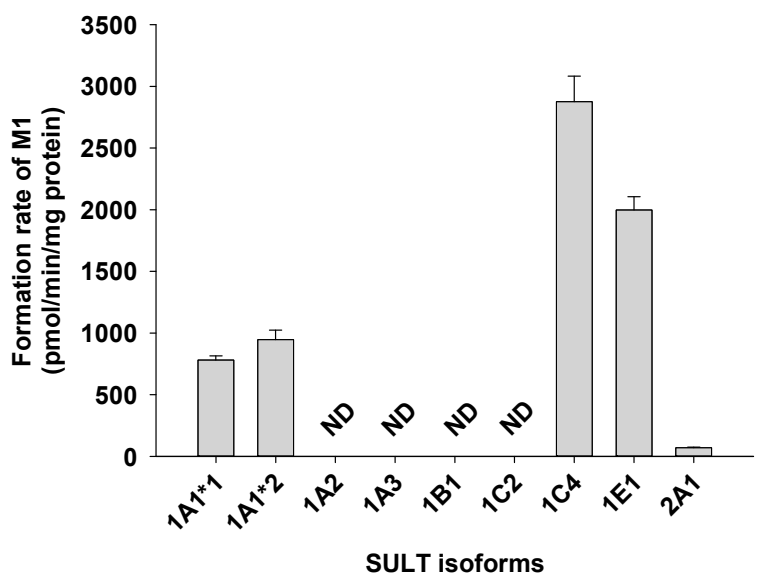

Figure 4. Rate of formation of catalposide sulfate (M1) from $150 \mu \mathrm{M}$ catalposide by human cDNA-expressed SULT enzymes. All data are means \pm SD $(n=3)$. ND: $<32 \mathrm{pmol} / \mathrm{min} / \mathrm{mg}$ protein.

The formation of catalposide sulfate from catalposide catalyzed by SULTs $1 \mathrm{~A} 1 * 1,1 \mathrm{~A} 1 * 2$, and 1E1 exhibited substrate inhibition kinetics, but the activities of SULT1C4 and pooled human liver S9 fractions fitted the Hill equation (Figure 5). The enzyme kinetic parameters for the formation of catalposide sulfate from catalposide are listed in Table 2. SULT1C4 exhibited a higher affinity for catalposide and more rapid sulfation than did SULT1A1*1, SULT1A1*2, and SULT1E1.

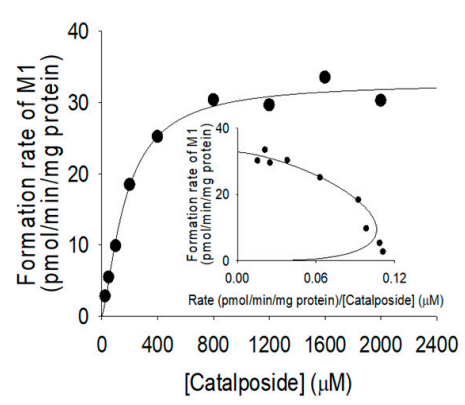

B

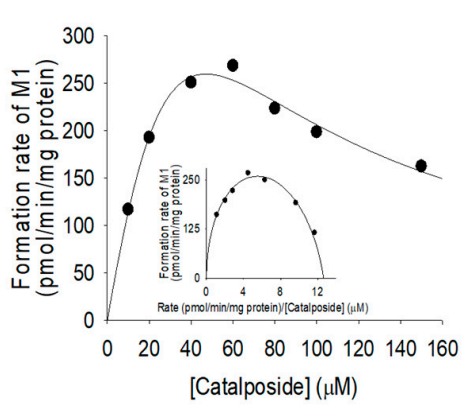

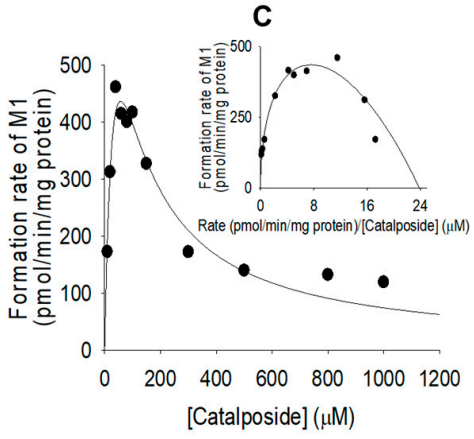

E
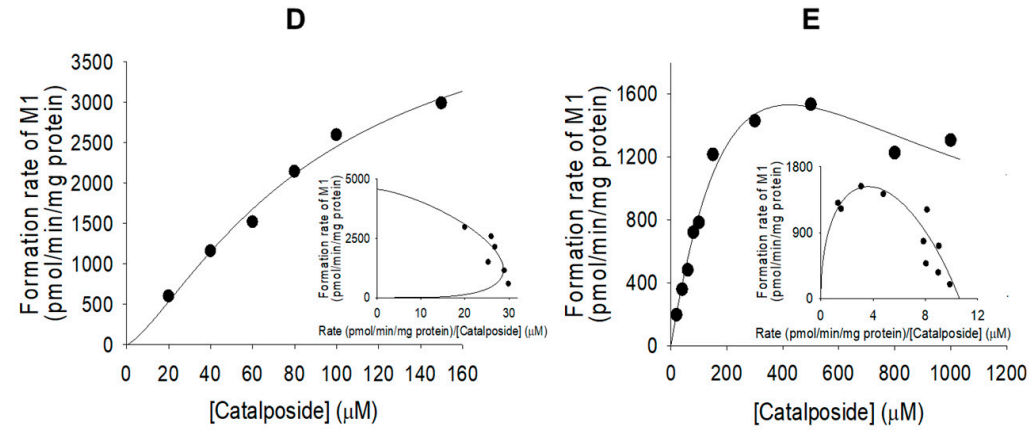

Figure 5. Michaelis-Menten plots of the sulfation of catalposide to catalposide sulfate (M1) by pooled human liver S9 fractions (A) and human cDNA-expressed SULT1A1*1 (B), SULT1A1*2 (C), SULT1C4 (D), and SULT1E1 (E). Insets: Eadie-Hofstee plots. Each data point represents the average of two determinations. 
Table 2. Kinetic parameters for the formation of catalposide sulfate (M1) and catalposide glucuronide (M4) from catalposide in pooled human liver S9 fractions, intestinal microsomes, and human cDNA-expressed sulfotransferase (SULT) or UDP-glucuronosyltransferase (UGT) enzymes.

\begin{tabular}{cccccc}
\hline Enzyme & $\boldsymbol{K}_{\mathbf{m}}(\boldsymbol{\mu M})$ & $V_{\mathbf{m a x}}$ & $\boldsymbol{K}_{\mathbf{i}}(\mu \mathbf{M})$ & $n$ & $C l_{\mathbf{i n t}}$ \\
\hline Sulfation of catalposide to M1 & & & & & \\
\hline SULT1A1 ${ }^{*}$ & 162.0 & 2046.8 & 13.7 & - & 12.6 \\
SULT1A1 $^{*}$ & 50.5 & 1203.2 & 65.5 & - & 23.8 \\
SULT1C4 & 89.8 & 4576.2 & - & 1.4 & 51.0 \\
SULT1E1 & 456.6 & 4840.0 & 391.4 & - & 10.6 \\
Human liver S9 fractions & 169.7 & 32.8 & - & 1.4 & 0.19 \\
\hline Glucuronidation of catalposide to M4 & 1230.1 & 48.7 & - & 0.9221 & 0.0396 \\
UGT1A8 & 641.7 & 218.1 & - & 2.3 & 0.3399 \\
UGT1A10 & 1341.3 & 106.2 & - & - & 0.0792 \\
\hline
\end{tabular}

$V_{\text {max }}: \mathrm{pmol} / \mathrm{min} / \mathrm{mg}$ protein; $C l_{\text {int }}: \mu \mathrm{L} / \mathrm{min} / \mathrm{mg}$ protein; $n$ : Hill coefficient.

A screen using human cDNA-expressed UGTs 1A1, 1A3, 1A4, 1A6, 1A7, 1A8, 1A9, 1A10, 2B4, 2B7, 2B15, and 2B17 supersomes for the metabolism of 4-hydroxybenzoic acid (M2) to 4-hydroxybenzoic acid glucuronide (M3) identified possible roles of UGT1A6 and UGT1A9 (Figure 6A). The results show that 4-hydroxybenzoic acid glucuronide (M3) was produced on incubation of catalposide with human hepatocytes, liver S9 fractions, and intestinal microsomes.

A

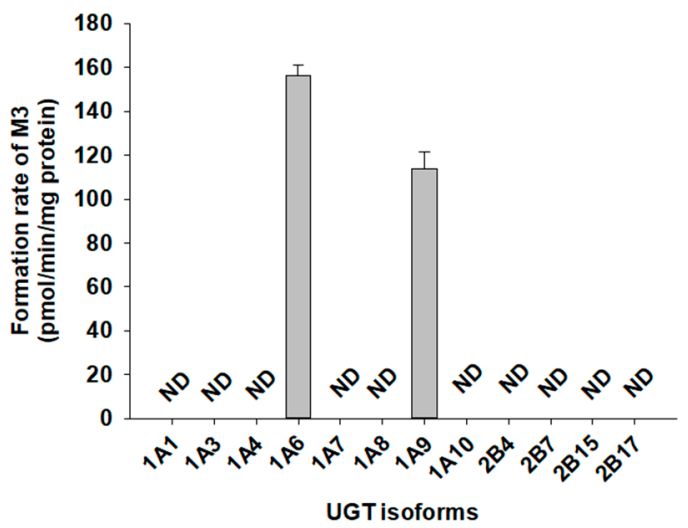

B

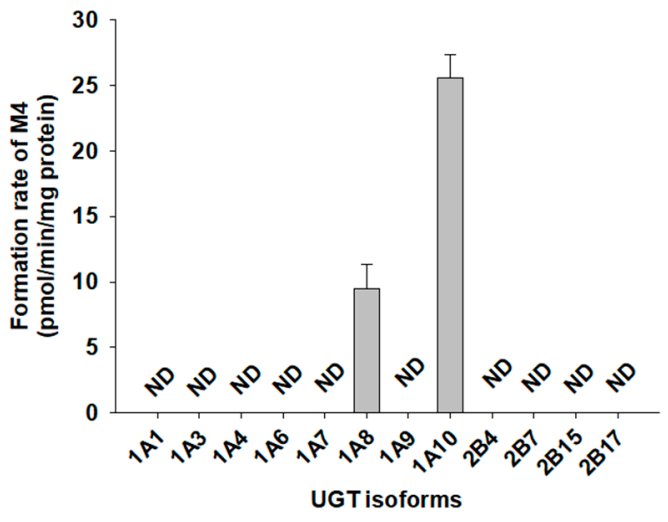

Figure 6. Rates of formation of (A) 4-hydroxybenzoic acid glucuronide (M3) from $500 \mu \mathrm{M}$ 4-hydroxybenzoic acid (M2) and (B) catalposide glucuronide (M4) from $400 \mu \mathrm{M}$ catalposide by human cDNA-expressed UGT enzymes. All data are means $\pm \mathrm{SD}(n=3)$. ND: $<27 \mathrm{pmol} / \mathrm{min} / \mathrm{mg}$ protein for $\mathrm{M} 3,<0.83 \mathrm{pmol} / \mathrm{min} / \mathrm{mg}$ protein for M4.

A screen using twelve human cDNA-expressed UGT supersomes, to assess the metabolism of catalposide to catalposide glucuronide (M4), identified possible roles of gastrointestinal tract-specific UGT1A8 and UGT1A10 (Figure 6B). The results show that catalposide glucuronide (M4) was produced after incubation of catalposide with pooled human intestinal microsomes, but not human liver S9 fractions.

Formation of catalposide glucuronide (M4) from catalposide by pooled human intestinal microsomes followed single enzyme kinetics; formation via UGT1A8 and UGT1A10 exhibited Hill equation kinetics (Figure 7, Table 2). 
A

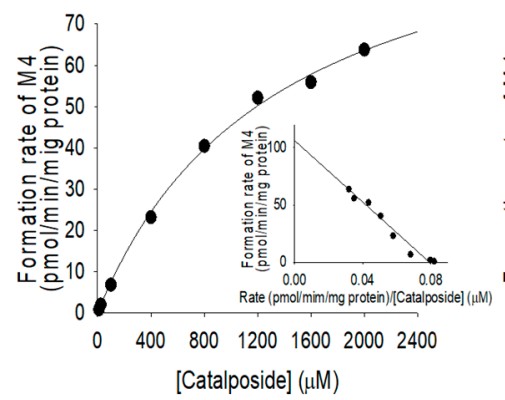

B

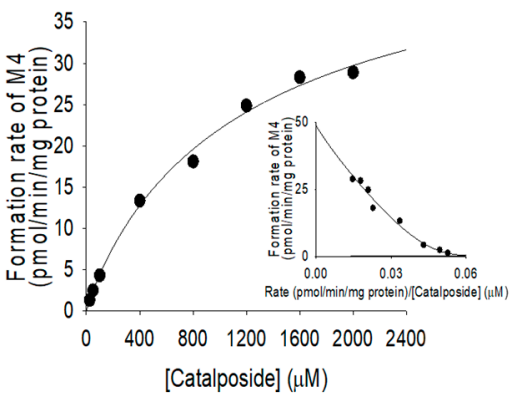

C

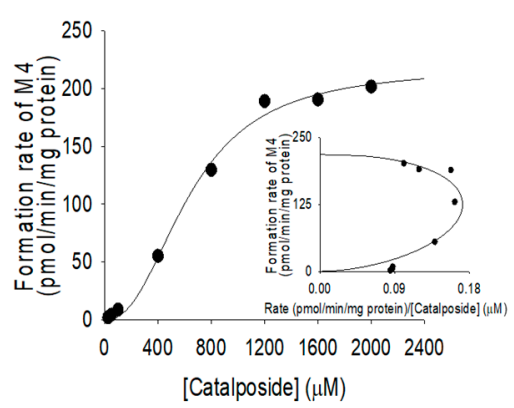

Figure 7. Michaelis-Menten plots for glucuronidation of catalposide to catalposide glucuronide (M4) by pooled human intestinal microsomes (A) and human cDNA-expressed UGT1A8 (B) and UGT1A10 (C). Insets: Eadie-Hofstee plots. Each data point represents the average of two determinations.

4-Hydroxybenzoic acid (M2) was formed from catalposide by pooled human liver S9 fractions; intestinal microsomes; and the CES1b, CES1c, and CES2 enzymes (Figure 8). The rate of formation of 4-hydroxybenzoic acid (M2) after incubation of catalposide with pooled human intestinal microsomes was higher than that after incubation with pooled human liver S9 fractions (Figure 8).

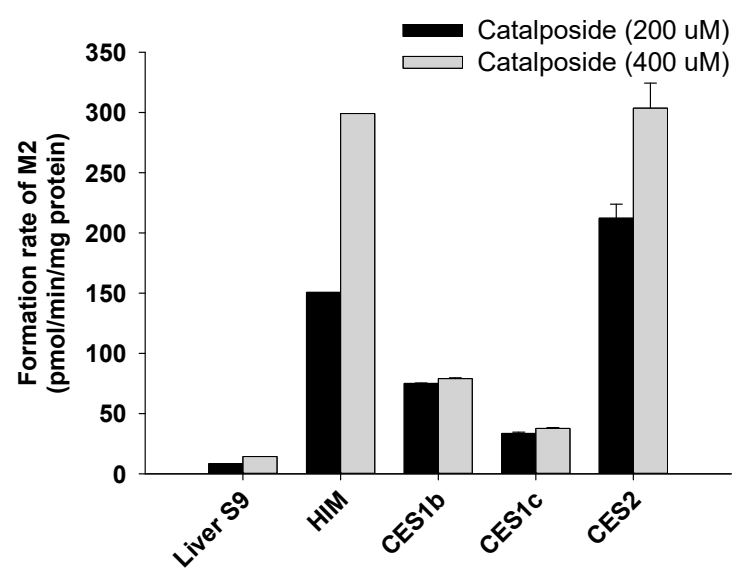

Figure 8. Rates of formation of 4-hydroxybenzoic acid (M2) from $200 \mu \mathrm{M}$ and $400 \mu \mathrm{M}$ catalposide in human liver S9 fractions (Liver S9); human intestinal microsomes (HIM); and human cDNA-expressed CES1b, CES1c, and CES2 enzymes. All data are means $\pm \operatorname{SD}(n=3)$.

\section{Discussion}

Catalposide was metabolized to catalposide sulfate (M1), catalposide glucuronide (M4), 4-hydroxybenzoic acid (M2), and M2 glucuronide (M3) by human hepatocytes or intestinal microsomes (Figure 3). On the basis of the kinetics of catalposide sulfate (M1) formation from catalposide catalyzed by human cDNA-expressed SULTs $1 \mathrm{~A} 1{ }^{*} 1,1 \mathrm{~A} 1 * 2,1 \mathrm{C} 4$, and $1 \mathrm{E} 1$ (Figure 4, Table 2), we suggest that SULT1A1, SULT1C4, and SULT1E1 may play major roles in this metabolism. SULT1C4 exhibited higher activity $\left(\mathrm{Cl}_{\text {int }}, 51.0 \mu \mathrm{L} / \mathrm{min} / \mathrm{mg}\right.$ protein $)$ in terms of catalposide sulfation than did SULT1A1*1, SULT1A1 $* 2$, or SULT1E1 $\left(\mathrm{Cl}_{\text {int }}, 10.6 \sim 23.8 \mu \mathrm{L} / \mathrm{min} / \mathrm{mg}\right.$ protein) (Table 2$)$. SULT1C4 is highly expressed in the fetal lung and kidney, and at lower levels in the fetal heart, adult kidney, ovary, brain, and spinal cord [21-23]. SULT1A1 is the major hepatic SULT (53\% of total hepatic SULTs), but is also present in substantial quantities in the small intestine (19\% of total SULTs) [23,24]. SULT1E1 is expressed at relatively low levels in the liver ( $6 \%$ of total SULTs) and small intestine ( $8 \%$ of total SULTs), but is the most abundant enzyme in the lung (40\% of total SULTs) [23,24]. Catalposide was metabolized to M1 by cytosolic SULTs of both hepatic and extrahepatic tissues. There may be inter-individual variability in catalposide sulfation, given that SULT1A1, SULT1C4, and SULT1E1 polymorphisms are known in humans [25]. SULT1A1, SULT1C4, and SULT1E1 are induced or inhibited by various drugs 
and chemicals [26,27]; therefore, co-administration of drugs that inhibit or induce expression of these enzymes may affect catalposide sulfation and thus catalposide pharmacokinetics.

Metabolism of catalposide to catalposide glucuronide (M4) was mediated by human cDNA-expressed UGT1A8 and UGT1A10 enzymes, which are confined to the gastrointestinal tract [28-32] (Figure 7), indicating that catalposide glucuronidation was gastrointestinal tract-specific; glucuronidation was not detected after incubation of catalposide with human hepatocytes and liver S9 fractions. UGT1A10-catalyzed catalposide glucuronidation was more extensive $\left(\mathrm{Cl}_{\text {int }}\right.$, $0.3399 \mu \mathrm{L} / \mathrm{min} / \mathrm{mg}$ protein) than UGT1A8-catalyzed glucuronidation $\left(\mathrm{Cl}_{\text {int }}, 0.0396 \mu \mathrm{L} / \mathrm{min} / \mathrm{mg}\right.$ protein $)$ (Table 2). UGT1A10 is more abundant than UGT1A8 in the small intestine (17.3\% vs. $0.8 \%$ of total UGT protein) and colon (27.4\% vs. $1.5 \%$ of total UGT protein) [32]. Thus, UGT1A10 may play the major role in glucuronidation of catalposide and UGT1A8 only a minor role. The human UGT1A8 and UGT1A10 enzymes are inhibited by various drugs [30,32-35]. Therefore, co-administration of drugs that inhibit or induce UGT1A8 and UGT1A10 may affect catalposide glucuronidation.

CES2, the predominant CES of the intestine, was more active in terms of hydrolysis of catalposide to 4-hydroxybenzoic acid (M2) than were the hepato-predominant CES1b and CES1c enzymes [32,36]. Thus, the rate of formation of 4-hydroxybenzoic acid (M2) was higher when catalposide was incubated with pooled human intestinal microsomes than with pooled human liver S9 fractions.

UGT1A6 and UGT1A9 play major roles in the formation of 4-hydroxybenzoic acid glucuronide (M3) from 4-hydroxybenzoic acid (Figure 6A). Abbas et al. [37] found that UGT1A9 played the major role in metabolism of 4-hydroxybenzoic acid to 4-hydroxybenzoic acid glucuronide. UGT1A6 and UGT1A9 are major enzymes of both the liver and intestine; therefore, 4-hydroxybenzoic acid glucuronide (M3) was identified after incubation of catalposide with either human hepatocytes or intestinal microsomes.

\section{Conclusions}

Catalposide was metabolized to catalposide sulfate (M1), 4-hydroxybenzoic acid (M2), M2 glucuronide (M3), and catalposide glucuronide (M4) via sulfation, glucuronidation, and hydrolysis, on incubation with human hepatocytes, liver S9 fractions, or intestinal microsomes. SULT1A1, SULT1C4, and SULT1E1 formed catalposide sulfate (M1) from catalposide. Gastrointestine-specific UGT1A8 and UGT1A10 played major roles in formation of catalposide glucuronide (M4). CES2 and CES1 catalyzed hydrolysis of catalposide to 4-hydroxybenzoic acid (M2), which was further metabolized to M2 glucuronide (M3) by UGT1A6 and UGT1A9. These results suggest that SULT1A1, SULT1C4, SULT1E1, UGT1A8, UGT1A10, CES2, and CES1 enzymes may play important roles in the pharmacokinetics and drug-drug interaction of catalposide in humans. The pharmacokinetics of catalposide may be dramatically affected by the co-administration of inhibitors or inducers of UGTs, CESs, or SULTs.

Author Contributions: Conceptualization, D.-K.H. and H.S.L.; methodology, D.-K.H., W.-G.C., Y.S., and S.K.; software, D.-K.H. and J.-H.K.; investigation, D.-K.H., W.-G.C., Y.S., and S.K.; data curation, D.-K.H., Y.S., J.-H.K., and H.S.L.; writing —original draft preparation, D.-K.H., J.-H.K., and Y.S.; writing-review and editing, Y.-Y.C., J.Y.L., H.C.K., and H.S.L.; supervision, H.S.L.; project administration, H.S.L.; funding acquisition, H.C.K. and H.S.L.

Funding: This work was supported by the National Research Foundation of Korea (NRF) grant funded by the Korea government (MSIT) (NRF-2015M3A9E1028325, NRF-2017M3A9F5028608, and NRF-2017R1A4A1015036).

Conflicts of Interest: The authors declare no conflict of interest.

\section{References}

1. Harput, U.S.; Saracoglu, I.; Inoue, M.; Ogihara, Y. Phenylethanoid and Iridoid Glycosides from Veronica persica. Chem. Pharm. Bull. 2002, 50, 869-871. [CrossRef] [PubMed]

2. Harput, U.S.; Saracoglu, I.; Nagatsu, A.; Ogihara, Y. Iridoid Glucosides from Veronica hederifolia. Chem. Pharm. Bull. 2002, 50, 1106-1108. [CrossRef] [PubMed]

3. Harput, U.; Varel, M.; Nagatsu, A.; Saracoglu, I. Acylated iridoid glucosides from Veronica anagallis-aquatica. Phytochemistry 2004, 65, 2135-2139. [CrossRef] [PubMed] 
4. Oh, H.; Pae, H.O.; Oh, G.S.; Lee, S.Y.; Chai, K.Y.; Song, C.E.; Kwon, T.O.; Chung, H.T.; Lee, H.S. Inhibition of Inducible Nitric Oxide Synthesis by Catalposide from Catalpa ovata. Planta Med. 2002, 68, 685-689. [CrossRef] [PubMed]

5. An, S.; Pae, H.; Oh, G.; Choi, B.; Jeong, S.; Jang, S.; Oh, H.; Kwon, T.; Song, C.E.; Chung, H. Inhibition of TNF- $\alpha$, IL-1 $\beta$, and IL- 6 productions and NF- $\mathrm{BB}$ activation in lipopolysaccharide-activated RAW 264.7 macrophages by catalposide, an iridoid glycoside isolated from Catalpa ovata G. Don (Bignoniaceae). Int. Immunopharmacol. 2002, 2, 1173-1181. [CrossRef]

6. Moon, M.K.; Choi, B.M.; Oh, G.S.; Pae, H.O.; Kim, J.D.; Oh, H.; Oh, C.S.; Kim, D.H.; Rho, Y.D.; Shin, M.K.; et al. Catalposide protects Neuro 2A cells from hydrogen peroxide-induced cytotoxicity via the expression of heme oxygenase-1. Toxicol. Lett. 2003, 145, 46-54. [CrossRef]

7. Kim, S.W.; Choi, S.C.; Choi, E.Y.; Kim, K.S.; Oh, J.M.; Lee, H.J.; Oh, H.M.; Kim, S.; Oh, B.S.; Kimm, K.C.; et al. Catalposide, a Compound Isolated from Catalpa Ovata, Attenuates Induction of Intestinal Epithelial Proinflammatory Gene Expression and Reduces the Severity of Trinitrobenzene Sulfonic Acid-Induced Colitis in Mice. Inflamm. Bowel Dis. 2004, 10, 564-572. [CrossRef]

8. Kupeli, E.; Harput, U.S.; Varel, M.; Yesilada, E.; Saracoglu, I. Bioassay-guided isolation of iridoid glucosides with antinociceptive and anti-inflammatory activities from Veronica anagallis-aquatica L. J. Ethnopharmacol. 2005, 102, 170-176. [CrossRef]

9. Lu, Q.; Sun, Y.; Shu, Y.; Tan, S.; Yin, L.; Guo, Y.; Tang, L. HSCCC Separation of the Two Iridoid Glycosides and Three Phenolic Compounds from Veronica ciliata and Their in Vitro Antioxidant and Anti-Hepatocarcinoma Activities. Molecules 2016, 21, 1234. [CrossRef]

10. Kwak, J.H.; Kim, H.J.; Lee, K.H.; Kang, S.C.; Zee, O.P. Antioxidative iridoid glycosides and phenolic compounds from Veronica peregrina. Arch. Pharmacal Res. 2009, 32, 207-213. [CrossRef]

11. Saracoglu, I.; Harput, U.S. In vitro cytotoxic activity and structure activity relationships of iridoid glucosides derived from Veronica species. Phytother. Res. 2012, 26, 148-152. [CrossRef] [PubMed]

12. Lee, J.H.; Jun, H.J.; Hoang, M.H.; Jia, Y.; Han, X.H.; Lee, D.H.; Lee, H.J.; Hwang, B.Y.; Lee, S.J. Catalposide is a natural agonistic ligand of peroxisome proliferator-activated receptor- $\alpha$. Biochem. Biophys. Res. Commun. 2012, 422, 568-572. [CrossRef] [PubMed]

13. Tan, S.; Lu, Q.; Shu, Y.; Sun, Y.; Chen, F.; Tang, L. Iridoid Glycosides Fraction Isolated from Veronica ciliata Fisch. Protects against Acetaminophen-Induced Liver Injury in Mice. Evid. Based Complement. Alternat. Med. 2017, 2017. [CrossRef] [PubMed]

14. Ji, H.Y.; Lee, H.W.; Kim, H.H.; Lee, H.I.; Chung, H.T.; Lee, H.S. Determination of Catalposide in Rat Plasma by Liquid Chromatography-Mass Spectrometry. Anal. Lett. 2003, 36, 2999-3009. [CrossRef]

15. Jeong, H.U.; Kwon, M.; Lee, Y.; Yoo, J.S.; Shin, D.H.; Song, I.S.; Lee, H.S. Organic anion transporter 3- and organic anion transporting polypeptides 1B1- and 1B3-mediated transport of catalposide. Drug Des. Dev. Ther. 2015, 9, 643-653.

16. Choi, W.G.; Kim, J.H.; Kim, D.K.; Lee, Y.; Yoo, J.S.; Shin, D.H.; Lee, H.S. Simultaneous Determination of Chlorogenic Acid Isomers and Metabolites in Rat Plasma Using LC-MS/MS and Its Application to A Pharmacokinetic Study Following Oral Administration of Stauntonia Hexaphylla Leaf Extract (YRA-1909) to Rats. Pharmaceutics 2018, 10, 143. [CrossRef] [PubMed]

17. Cerny, M.A. Prevalence of Non-Cytochrome P450-Mediated Metabolism in Food and Drug Administration-Approved Oral and Intravenous Drugs: 2006-2015. Drug Metab. Dispos. 2016, 44, 1246-1252. [CrossRef] [PubMed]

18. Foti, R.S.; Dalvie, D.K. Cytochrome P450 and non-Cytochrome P450 Oxidative Metabolism: Contributions to the Pharmacokinetics, Safety and Efficacy of Xenobiotics. Drug Metab. Dispos. 2016, 44, 1229-1245. [CrossRef] [PubMed]

19. Kim, J.H.; Hwang, D.K.; Moon, J.Y.; Lee, Y.; Yoo, J.S.; Shin, D.H.; Lee, H.S. Multiple UDP-Glucuronosyltransferase and Sulfotransferase Enzymes are Responsible for the Metabolism of Verproside in Human Liver Preparations. Molecules 2017, 22, 670. [CrossRef] [PubMed]

20. Jeong, H.U.; Kim, J.H.; Kong, T.Y.; Choi, W.G.; Lee, H.S. Comparative metabolism of honokiol in mouse, rat, dog, monkey, and human hepatocytes. Arch. Pharmacal Res. 2016, 39, 516-530. [CrossRef] [PubMed]

21. Suiko, M.; Kurogi, K.; Hashiguchi, T.; Sakakibara, Y.; Liu, M.C. Updated perspectives on the cytosolic sulfotransferases (SULTs) and SULT-mediated sulfation. Biosci. Biotech. Biochem. 2017, 81, 63-72. [CrossRef] [PubMed] 
22. Guidry, A.L.; Tibbs, Z.E.; Runge-Morris, M.; Falany, C.N. Expression, Purification, and Characterization of Human Cytosolic Sulfotransferase (Sult) 1c4. Horm. Mol. Boil. Clin. Investig. 2017, 29, 27-36. [CrossRef] [PubMed]

23. Coughtrie, M.W. Function and organization of the human cytosolic sulfotransferase (SULT) family. Chem. Interact. 2016, 259, 2-7. [CrossRef] [PubMed]

24. Riches, Z.; Stanley, E.L.; Bloomer, J.C.; Coughtrie, M.W.H. Quantitative Evaluation of the Expression and Activity of Five Major Sulfotransferases (SULTs) in Human Tissues: The SULT "Pie". Drug Metab. Dispos. 2009, 37, 2255-2261. [CrossRef] [PubMed]

25. Marto, N.; Morello, J.; Monteiro, E.C.; Pereira, S.A.; Morello, J.B. Implications of Sulfotransferase Activity in Interindividual Variability in Drug Response: Clinical Perspective on Current Knowledge. Drug Metab. Rev. 2017, 49, 357-371. [CrossRef] [PubMed]

26. James, M.O.; Ambadapadi, S. Interactions of cytosolic sulfotransferases with xenobiotics. Drug Metab. Rev. 2013, 45, 401-414. [CrossRef] [PubMed]

27. Zhou, T.; Chen, Y.; Huang, C.; Chen, G. Caffeine Induction of Sulfotransferases in Rat Liver and Intestine. J. Appl. Toxicol. 2012, 32, 804-809. [CrossRef] [PubMed]

28. Lv, X.; Zhang, J.B.; Hou, J.; Dou, T.Y.; Ge, G.B.; Hu, W.Z.; Yang, L. Chemical probes fpr human UDP-glucuronosyltransferases: A comprehensive review. Biotechnol. J. 2019, 14. [CrossRef] [PubMed]

29. Wang, H.; Cao, G.; Wang, G.; Hao, H. Regulation of Mammalian UDP-Glucuronosyltransferases. Curr. Drug Metab. 2018, 19, 490-501. [CrossRef]

30. Meech, R.; Hu, D.G.; McKinnon, R.A.; Mubarokah, S.N.; Haines, A.Z.; Nair, P.C.; Rowland, A.; MacKenzie, P.I. The UDP-Glycosyltransferase (UGT) Superfamily: New Members, New Functions, and Novel Paradigms. Physiol. Rev. 2019, 99, 1153-1222. [CrossRef]

31. Fallon, J.K.; Neubert, H.; Goosen, T.C.; Smith, P.C. Targeted Precise Quantification of 12 Human Recombinant Uridine-Diphosphate Glucuronosyl Transferase 1A and 2B Isoforms Using Nano-Ultra-High-Performance Liquid Chromatography/Tandem Mass Spectrometry with Selected Reaction Monitoring. Drug Metab. Dispos. 2013, 41, 2076-2080. [CrossRef] [PubMed]

32. Argikar, U.A.; Potter, P.M.; Hutzler, J.M.; Marathe, P.H. Challenges and opportunities with Non-CYP enzymes aldehyde oxidase, carboxylesterase, and UDP-Glucuronosyltransferase: Focus on reaction phenotyping and prediction of human clearance. AAPS J. 2016, 18, 1391-1405. [CrossRef] [PubMed]

33. Kiang, T.K.; Ensom, M.H.; Chang, T.K. UDP-glucuronosyltransferases and clinical drug-drug interactions. Pharmacol. Ther. 2005, 106, 97-132. [CrossRef]

34. Miners, J.O.; Mackenzie, P.I.; Knights, K.M. The prediction of drug-glucuronidation parameters in humans: UDP-glucuronosyltransferase enzyme-selective substrate and inhibitor probes for reaction phenotyping and in vitro-in vivo extrapolation of drug clearance and drug-drug interaction potential. Drug Metab. Rev. 2010, 42, 196-208. [CrossRef]

35. Parkinson, A.; Kazmi, F.; Buckley, D.B.; Yerino, P.; Ogilvie, B.W.; Paris, B.L. System-Dependent Outcomes during the Evaluation of Drug Candidates as Inhibitors of Cytochrome P450 (CYP) and Uridine Diphosphate Glucuronosyltransferase (UGT) Enzymes: Human Hepatocytes versus Liver Microsomes versus Recombinant Enzymes. Drug Metab. Pharmacok. 2010, 25, 16-27. [CrossRef]

36. Chen, F.; Zhang, B.; Parker, R.B.; Laizure, S.C. Clinical implications of genetic variation in carboxylesterase drug metabolism. Expert Opin. Drug Metab. Toxicol. 2018, 14, 131-142. [CrossRef]

37. Abbas, S.; Greige-Gerges, H.; Karam, N.; Piet, M.H.; Netter, P.; Magdalou, J. Metabolism of Parabens (4-Hydroxybenzoic Acid Esters) by Hepatic Esterases and UDP-Glucuronosyltransferases in Man. Drug Metab. Pharmacok. 2010, 25, 568-577. [CrossRef]

(C) 2019 by the authors. Licensee MDPI, Basel, Switzerland. This article is an open access article distributed under the terms and conditions of the Creative Commons Attribution (CC BY) license (http://creativecommons.org/licenses/by/4.0/). 